\title{
O MÉDICO E A MÍDIA
}

Vivemos a era da informação. Neste sentido, vem se tornando cada vez mais freqüente o papel da mídia na divulgação de informações científicas. Nas áreas de ciências biológicas e medicina, são publicados anualmente mais de 2 milhões de artigos científicos. Atrás de informações sobre sua saúde, nossos pacientes consultam o "Dr. Web" e trazem aos médicos artigos e opiniões sobre suas doenças. Além disso, quando um personagem famoso está doente, existe a pressão da curiosidade da opinião pública para saber os detalhes sobre o caso.

A participação do paciente e de seus familiares nas decisões clínicas sobre testes diagnósticos e intervenções terapêuticas é muito importante. Por isso, o conhecimento sobre os benefícios, riscos e alternativas ao tratamento proposto devem ser sempre esclarecidos pela equipe médica. A busca e a troca de informações adicionais por parte do paciente é parte do padrão cultural popular e deve ser encarada como um reforço bem-vindo ao invés de um incômodo a ser evitado. Por outro lado, a formação e o conhecimento são instrumentos importantes para uma avaliação crítica das informações médicas disponíveis na mídia. Numa era onde a informação é divulgada de forma muito rápida e com baixo custo, especialmente na internet, podem ser encontradas informações de fontes não confiáveis e, muito pior, repletas de erros e conceitos inadequados e até perigosos.

As decisões médicas baseiam-se em três pilares: a melhor evidência científica, a experiência clínica e os aspectos éticos. Todos esses aspectos fazem parte da longa formação cultural do médico. Não é possível imaginar que todo indivíduo seja capaz de compreender, em um curto espaço de tempo, o conhecimento médico. Por outro lado, não é correto presumir que este conhecimento seja prerrogativa do médico. A história da divulgação do conhecimento em nossa sociedade revela esta natureza especulativa e curiosa dos "não especialistas" muito antes dos computadores ou mesmo da moderna medicina.

Mas existem barreiras que são intransponíveis. Os avanços tecnológicos e científicos geralmente têm um grande efeito sobre a mídia, embora representem, de imediato, um impacto pequeno na evolução clínica dos pacientes. O relacionamento com a mídia deve ser cuidadoso no sentido de explicar a realidade da informação científica e seu lugar na prática clínica.

Mais delicada e importante, entretanto, é a confidencialidade das informações. O respeito ao sigilo é fundamental. A preservação de segredos profissionais é um direito do paciente e uma conquista da sociedade contida nos Códigos de Ética e Penal. Esta relação de confiança se estabelece entre o paciente e seu médico e se estende a todos os demais profissionais das áreas de saúde e administração que tenham contato direto ou indireto com as informações obtidas. Segundo Francisconi e Goldim, boa parte do vínculo que se estabelece entre médico e paciente pode ser creditado a esta garantia. A formação ética do médico é muito importante para que o respeito ao paciente seja mantido.

Finalmente, a importância de hábitos salutares, o valor de um exame de triagem na detecção precoce de uma doença curável, em especial nas situações em que o caráter preventivo está bem estabelecido, mostra que a mídia pode ser um grande e poderoso aliado. Ao reconhecer esta parceria, com respeito mútuo, médicos e profissionais de mídia estarão elevando ao mais nobre patamar a função de prestar serviço à sociedade, a razão da existência dessas duas profissões. 